\title{
Studies on Effect of Metsulfuron Methyl on Chlorophyll, Sugar Content in Wheat Leaves and Its Relationship with Grain Sugar Content
}

\author{
Nitasha Thakur ${ }^{1 *}$, Neelam Sharma ${ }^{2}$ and Yeshwant Singh ${ }^{3}$ \\ ${ }^{1}$ Department of Crop physiology, Biochemistry and Post-harvest technology, CPRI, \\ Shimla-171001, India \\ ${ }^{2}$ Department of Chemistry \& Biochemistry, CSKHPKV, Palampur, HP-176062, India \\ ${ }^{3}$ Analytical Development Division, Sun Pharma Advanced Research Company (SPARC), \\ Vadodara, Gujarat-390 020, India \\ *Corresponding author
}

\begin{abstract}
A B S T R A C T
Keywords

Wheat, Metsulfuron methyl,

Chlorophyll, Sugar,

Herbicide efficiency

Article Info

Accepted:

16 April 2018

Available Online:

10 May 2018

A field experiment was laid out in randomized block design consisting of metsulfuron methyl (a herbicide) treatments at 2, 4, $8 \mathrm{~g} /$ ha during two consecutive years. The experiment was designed to study its effect on biochemical attributes viz. total chlorophyll, chlorophyll ' $a$ ', chlorophyll ' $b$ ' and total sugar content of wheat crop. Wheat plant samples were collected at $0(2 \mathrm{~h}), 15,30,45,60,75$ and 90 days after herbicide application. In general, an increase in the total chlorophyll, chlorophyll ' $a$ ', chlorophyll ' $b$ ' and total sugar content was observed after metsulfuron methyl treatment in wheat leaves. The results also revealed that among all the three metsulfuron methyl treatments, highest value of chlorophyll content, sugars content in plant and sugar content in wheat grain was observed in metsulfuron methyl $4 \mathrm{~g} \mathrm{ha}^{-1}$ (recommended dose) suggesting weed control efficiency is maximum at recommended dose and indicated the positive correlation between chlorophyll and carbohydrate content at all stages of sampling. Based on the results of our study, it could be concluded that the metsulfuron methyl at recommended dose have a nonsignificant effect on the biochemical attributes of wheat and can be used by farmers for better yield of crop.
\end{abstract}

\section{Introduction}

Wheat is one of the premier and widely cultivated cereal crops of the world. In India, it is the second most important source of staple food next to rice. It provides nearly 55 per cent of the carbohydrates and 20 per cent of the food calories consumed globally. Wheat is cultivated worldwide in more than 232 million hectares with a production of 595 million tonnes (Chitband et al., 2013). India shares 12.40 percent of the global wheat cropped area and 12.03 per cent of global wheat production. In Himachal Pradesh, wheat occupies an area of 330.35 thousand hectare with an annual production of 544.44 thousand tonnes (Anonymous 2012-13).

This crop is heavily infested with weeds and on an average reduced grain yield by 66 
percent (Kumar et al., 2009). Therefore, herbicides form the principal component of weed management in wheat.

Sulfonylurea is a family of herbicides that is widely used because of its low application rate (2-100 $\mathrm{g} \mathrm{ha}^{-1}$ ), high herbicidal effect, broad action spectrum, good crop selectivity and low human and animal toxicity (Zanardini et al., 2002). Metsulfuron methyl (Methyl-2-(4methoxy-6-methyl-1,3,5-triazin-2-yl

carbamoyl sulfamoyl) benzoate) belonging to this family is a selective, systemic, postemergence herbicide, used to control broad leaved weeds in rice, wheat, rye, barley, pasture, plantation crop and non-cropped situation (Singh and Singh,2002). It acts as an inhibitor of the enzyme acetolactate synthase which retards cell division in the shoots and roots of the plant.

Metsulfuron methyl is rapidly taken by plants through the roots and foliage with rapid translocation both acropetally and basipetally. Although, herbicide usage contributes a gainful increment in crop production by way of controlling the weeds and promoting the crop growth and development but once translocated through xylem and phloem, metsulfuron methyl alters the metabolism of plant and effects many biochemical and physiological processes (Brown, 1990). Metsulfuron methyl also induces inhibition in cyclic, non-cyclic phosphorylation and carbon dioxide fixation and increase in ethylene production (Blair and Martin, 1988). Herbicidal effects may result from a direct depletion of the end products, from depletion of intermediates of the pathway for some critical processes, or from a buildup of a toxic substrate. The mode of action of metsulfuron methyl are indicative of the fact that major biochemical quality attributes of wheat crop may get affected adversely by metsulfuron methyl application leading to quality deterioration of wheat.
Chlorophyll is an extremely important biomolecule, critical in photosynthesis, which allows plants to obtain energy from light. Sugars are the ultimate product of photosynthesis in which chlorophyll molecules play an important role. The rate of $\mathrm{CO}_{2}$ assimilation per unit time is determined by quantity of chlorophyll molecules and this assimilation rate of $\mathrm{CO}_{2}$ directly governs the total sugar content in leaves. The effect of herbicide on chlorophyll content will directly reflect its effect on photosynthesis. Increased use of herbicides in India may pose opportunity for drift of chemicals on nontargets also even though the herbicide application is target specific. Studies have also shown that the extremely low levels of metsulfuron methyl residues have phytotoxicity to sensitive crops in croprotation systems (Li et al., 2005). Keeping this in view, the present study was conducted to find out the influence of metsulfuron methyl on chlorophyll and sugar content in wheat under mid-hill conditions of Himachal Pradesh.

\section{Materials and Methods}

\section{Experimental design}

A field experiment consisting metsulfuron methyl treatments at 2, 4, 8g/ha, along with control (treatment with water) was conducted at the Research Farm of Department of Agronomy, CSKHPKV, Palampur, India in a randomized block design with five replications during two Rabi seasons. Plots of $4.1 \mathrm{~m} \times 2.0 \mathrm{~m}$ were prepared and sown with wheat variety HPW155 in $22.5 \mathrm{~cm}$ row spacing for each treatment. Prior to the commencement of study, the physicochemical properties of soil were determined in the field. The soil of the experimental field was silty clay loam in texture and acidic in nature $[\mathrm{pH}$ 5.6]. During both the years, metsulfuron methyl as Supergrip (WP) containing 20\% 
active ingredient was sprayed in the plots using a volume spray of 3 litre water/ha with the help of Knapsack sprayer with flat fan nozzle.

\section{Reagents and chemicals}

All solvents used in study were of analytical grade and purchased from Merck India Pvt. Ltd. Metsulfuron methyl was procured from Sigma Aldrich, India.

\section{Sample collection}

Plant samples were collected at 0 (2 h), 15, 30, 45, 60, 75, 90 days after herbicide application and at harvest (180 days). The plant samples were analyzed for biochemical estimation of chlorophyll a, chlorophyll b, total chlorophyll and total sugars. Wheat straw and wheat grain samples were collected at the maturity of crop for total sugars.

\section{Biochemical analysis of plant samples}

Chlorophyll a, chlorophyll b and total chlorophyll was extracted from fresh leaves using method described by Hiscox \& Israelstam (1979) and total sugars in wheat plant and grains were quantified by method adopted by Hedge and Hofreiter (1962) using spectrophotometer at $630 \mathrm{~nm}$. The data on various parameters recorded during the course of investigation were subjected to statistical analysis as per method given by Gomez and Gomez (1989).

\section{Results and Discussion}

\section{Total chlorophyll}

Irrespective of the treatments, total chlorophyll content in general decreased from zero to 30 days after herbicide application during both years of study (Table 1). Thereafter, it increased upto 60 days after herbicide application and then decreased at 75 and 90 days after herbicide application. During both years of experiment at all the observation stages i.e. $0,15,30,45,60,75$ and 90 days after herbicide application the data on total chlorophyll content in wheat leaves was found to be significant except at zero day after herbicide application during first year. During second year at zero day after herbicide application significantly higher value of total chlorophyll content in wheat leaves was observed in metsulfuron methyl $4 \mathrm{~g} \mathrm{ha}^{-1}$ (2.78 $\mathrm{mg} \mathrm{g}^{-1}$ ) followed by metsulfuron methyl $2 \mathrm{~g}$ $\mathrm{ha}^{-1}\left(2.45 \mathrm{mg} \mathrm{g}^{-1}\right)$. However, metsulfuron methyl $2 \mathrm{~g} \mathrm{ha}^{-1}\left(2.45 \mathrm{mg} \mathrm{g}^{-1}\right)$ behaved statistically similar with metsulfuron methyl 8 $\mathrm{g} \mathrm{ha}^{-1}\left(2.33 \mathrm{mg} \mathrm{g}^{-1}\right)$. Significantly lowest value for total chlorophyll content in wheat leaves was recorded in control $\left(2.19 \mathrm{mg} \mathrm{g}^{-1}\right)$.

At 15 days after herbicide application during first year, the data revealed that metsulfuron methyl $4 \mathrm{~g} \quad \mathrm{ha}^{-1}$ (1.61 $\left.\mathrm{mg} \mathrm{g}^{-1}\right)$ being statistically at par with metsulfuron methyl $2 \mathrm{~g}$ $\mathrm{ha}^{-1}\left(1.59 \mathrm{mg} \mathrm{g}{ }^{-1}\right)$ resulted into maximum value for total chlorophyll in wheat leaves. Control (1.55 mg g ${ }^{-1}$ ) behaved statistically similar with metsulfuron methyl $8 \mathrm{~g} \mathrm{ha}^{-1}$ (1.58 $\mathrm{mg} \mathrm{g}^{-1}$ ) obtained minimum value of total chlorophyll content in wheat leaves. During second year, significantly higher value for total chlorophyll content in wheat leaves was obtained in metsulfuron methyl $4 \mathrm{~g}^{-1}(1.84$ $\left.\mathrm{mg}^{-1}\right)$ followed by metsulfuron methyl $2 \mathrm{~g}$ $\mathrm{ha}^{-1}\left(1.77 \mathrm{mg} \mathrm{g}^{-1}\right)$ and metsulfuron methyl $8 \mathrm{~g}$ $\mathrm{ha}^{-1}\left(1.73 \mathrm{mg} \mathrm{g}^{-1}\right)$. Significantly lower value was observed in control $\left(1.66 \mathrm{mg} \mathrm{g}^{-1}\right)$ for total chlorophyll content.

Observations at 30 and 45 days after herbicide application during first year revealed that significantly higher values for total chlorophyll content in wheat leaves was obtained in treatment metsulfuron methyl $4 \mathrm{~g}$ $\mathrm{ha}^{-1}\left(1.51 \mathrm{mg} \mathrm{g}^{-1}\right.$ at 30 days and $1.57 \mathrm{mg} \mathrm{g}^{-1}$ at 45 days after herbicide application). Treatment 
metsulfuron methyl $2 \mathrm{~g} \mathrm{ha}^{-1}$ behaving statistically similar with metsulfuron methyl 8 $\mathrm{g} \mathrm{ha}^{-1}$ showed the same numerical values $(1.45$ $\mathrm{mg} \mathrm{g}^{-1}$ at 30 days and $1.53 \mathrm{mg} \mathrm{g}^{-1}$ at 45 days after herbicide application) for total chlorophyll in wheat leaves. At both stages of observation, significantly lowest value was observed in control. During second year of study, the values for total chlorophyll in wheat leaves varied from 1.68 to $1.56 \mathrm{mg} \mathrm{g}^{-1}$ at 30 days after herbicide application and 1.74 to $1.60 \mathrm{mg} \mathrm{g}^{-1}$ at 45 days after herbicide application with maximum and minimum values exhibited by metsulfuron methyl $4 \mathrm{~g}$ $\mathrm{ha}^{-1}$ and control respectively. At further observation stages i.e. 60, 75 and 90 days after herbicide application during both the years of study, metsulfuron methyl $4 \mathrm{~g} \mathrm{ha}^{-1}$ maintained its superiority over all treatment. The next best treatment recorded for total chlorophyll in wheat leaves was metsulfuron methyl $2 \mathrm{~g} \mathrm{ha}^{-1}$ followed by metsulfuron methyl $8 \mathrm{~g} \mathrm{ha}^{-1}$. Significantly lower value for total chlorophyll content in wheat leaves was observed in control during both years.

\section{Chlorophyll ' $a$ '}

During both years of study, chlorophyll ' $a$ ' content in wheat leaves decreased from zero to 30 days after herbicide application, increased from 45 to 60 days after herbicide application and thereafter declined from 75 days after herbicide application. A similar trend of herbicide effect was observed in chlorophyll ' $a$ ' as that of total chlorophyll in wheat leaves (Table 2). At all the observation stages i.e. 0, 15, 30, 45, 60, 75 and 90 days after herbicide application during both years, a significant variation in chlorophyll 'a' content was observed except at zero day after herbicide application during first year where the data was found to be non- significant. At all the observation stages i.e. $0,15,30,45,60,75$ and 90 days after herbicide application, the maximum value of chlorophyll ' $a$ ' in wheat leaves was observed in metsulfuron methyl 4 $\mathrm{g} \mathrm{ha}^{-1}$ and this treatment maintained superiority over all other treatments. Significantly minimum value for chlorophyll ' $a$ ' in wheat leaves was observed in control at all the observation stages.

\section{Chlorophyll ' $b$ '}

Chlorophyll ' $b$ ' is an accessory pigment and acts indirectly in photosynthesis by transferring light it absorbs to chlorophyll ' $a$ '. A perusal of data embodied in table 3 showed the effect of different metsulfuron methyl treatments on chlorophyll ' $b$ ' content of wheat leaves for the two rabi season. Irrespective of the treatments, in general during both years chlorophyll ' $b$ ' in wheat leaves decreased from zero to 30 days after herbicide application and then increased from 45 to 60 days. Thereafter, a decrease in chlorophyll content ' $b$ ' in wheat leaves was observed at later stages of sampling. At all the observation stages i.e. $0,15,30,45,60,75$ and 90 days after herbicide application, the data was found to be significant showing that metsulfuron methyl influenced the chlorophyll content ' $b$ ' in wheat leaves. At each of observation stages during both seasons significantly highest value of chlorophyll content ' $b$ ' in wheat leaves was recorded in metsulfuron methyl $4 \mathrm{~g} \mathrm{ha}^{-1}$ followed by metsulfuron methyl $2 \mathrm{~g} \mathrm{ha}^{-1}$ and metsulfuron methyl $8 \mathrm{~g} \mathrm{ha}^{-1}$. However, metsulfuron methyl $4 \mathrm{~g} \mathrm{ha}^{-1}$ remained statistically at par with metsulfuron methyl $2 \mathrm{~g}$ $\mathrm{ha}^{-1}$ at 15, 30 and 45 days after herbicide application during first year. In general, lowest value for chlorophyll ' $b$ ' in wheat leaves was observed in control during both years of study. A perusal of data on variability in total chlorophyll, chlorophyll 'a' and chlorophyll ' $b$ ' content in wheat leaves revealed that there was a significant increase in all the metsulfuron methyl treatments over control at all the observation stages during both years of study. 
Table.1 Effect of different treatments of metsulfuron methyl on total chlorophyll $\left(\mathrm{mg} \mathrm{g}^{-1}\right)$ in wheat leaves at different time intervals

\begin{tabular}{|c|c|c|c|c|c|c|c|c|c|c|c|c|c|c|}
\hline \multirow[t]{3}{*}{ Treatments } & & & \multicolumn{12}{|c|}{ Days after herbicide application } \\
\hline & \multicolumn{2}{|c|}{$\mathbf{0}$} & \multicolumn{2}{|c|}{15} & \multicolumn{2}{|c|}{30} & \multicolumn{2}{|c|}{45} & \multicolumn{2}{|c|}{60} & \multicolumn{2}{|c|}{75} & \multicolumn{2}{|r|}{90} \\
\hline & $\begin{array}{l}\text { First } \\
\text { year }\end{array}$ & $\begin{array}{c}\text { Second } \\
\text { year }\end{array}$ & $\begin{array}{l}\text { First } \\
\text { year }\end{array}$ & $\begin{array}{c}\text { Second } \\
\text { year }\end{array}$ & $\begin{array}{l}\text { First } \\
\text { year }\end{array}$ & $\begin{array}{c}\text { Second } \\
\text { year }\end{array}$ & $\begin{array}{l}\text { First } \\
\text { year }\end{array}$ & $\begin{array}{c}\text { Second } \\
\text { year }\end{array}$ & $\begin{array}{l}\text { First } \\
\text { year }\end{array}$ & $\begin{array}{c}\text { Second } \\
\text { year }\end{array}$ & $\begin{array}{l}\text { First } \\
\text { year }\end{array}$ & $\begin{array}{c}\text { Second } \\
\text { year }\end{array}$ & $\begin{array}{l}\text { First } \\
\text { year }\end{array}$ & $\begin{array}{l}\text { Second } \\
\text { year }\end{array}$ \\
\hline $\begin{array}{l}\text { Metsulfuron } \\
\text { methyl } \\
2 \mathrm{~g} \mathrm{ha}^{-1}\end{array}$ & 1.94 & 2.45 & 1.59 & 1.77 & 1.45 & 1.66 & 1.53 & 1.69 & 1.76 & 1.84 & 1.32 & 1.61 & 1.20 & 1.45 \\
\hline $\begin{array}{l}\text { Metsulfuron } \\
\text { methyl } \\
4 \mathrm{~g} \mathrm{ha}^{-1}\end{array}$ & 1.98 & 2.78 & 1.61 & 1.84 & 1.51 & 1.68 & 1.57 & 1.74 & 1.86 & 1.90 & 1.38 & 1.68 & 1.25 & 1.52 \\
\hline $\begin{array}{l}\text { Metsulfuron } \\
\text { methyl } \\
8 \mathrm{~g} \mathrm{ha}^{-1}\end{array}$ & 1.93 & 2.33 & 1.58 & 1.73 & 1.45 & 1.60 & 1.53 & 1.65 & 1.71 & 1.81 & 1.28 & 1.56 & 1.20 & 1.36 \\
\hline Control & 1.87 & 2.19 & 1.55 & 1.66 & 1.34 & 1.56 & 1.46 & 1.60 & 1.67 & 1.72 & 1.25 & 1.51 & 1.15 & 1.37 \\
\hline$(P=0.05)$ & NS & 0.22 & 0.03 & 0.03 & 0.05 & 0.01 & 0.03 & 0.02 & 0.05 & 0.02 & 0.04 & 0.02 & 0.04 & 0.01 \\
\hline
\end{tabular}

Table.2 Effect of different treatments of metsulfuron methyl on chlorophyll ' $\mathrm{a}$ ' $\left(\mathrm{mg} \mathrm{g}^{-1}\right)$ in wheat leaves at different time intervals

\begin{tabular}{|c|c|c|c|c|c|c|c|c|c|c|c|c|c|c|}
\hline \multirow[t]{3}{*}{ Treatments } & & & \multicolumn{12}{|c|}{ Days after herbicide application } \\
\hline & \multicolumn{2}{|c|}{$\mathbf{0}$} & \multicolumn{2}{|c|}{15} & \multicolumn{2}{|c|}{30} & \multicolumn{2}{|c|}{45} & \multicolumn{2}{|c|}{60} & \multicolumn{2}{|c|}{75} & \multicolumn{2}{|c|}{90} \\
\hline & $\begin{array}{l}\text { First } \\
\text { year }\end{array}$ & $\begin{array}{l}\text { Second } \\
\text { year }\end{array}$ & $\begin{array}{l}\text { First } \\
\text { year }\end{array}$ & $\begin{array}{l}\text { Secon } \\
\text { d year }\end{array}$ & $\begin{array}{l}\text { First } \\
\text { year }\end{array}$ & $\begin{array}{l}\text { Secon } \\
\text { d year }\end{array}$ & $\begin{array}{l}\text { First } \\
\text { year }\end{array}$ & $\begin{array}{l}\text { Secon } \\
\text { d year }\end{array}$ & $\begin{array}{l}\text { First } \\
\text { year }\end{array}$ & $\begin{array}{l}\text { Secon } \\
\text { d year }\end{array}$ & $\begin{array}{l}\text { First } \\
\text { year }\end{array}$ & $\begin{array}{l}\text { Secon } \\
\text { d year }\end{array}$ & $\begin{array}{l}\text { First } \\
\text { year }\end{array}$ & $\begin{array}{l}\text { Second } \\
\text { year }\end{array}$ \\
\hline $\begin{array}{l}\text { Metsulfuron methyl } \\
2 \mathrm{~g} \mathrm{ha}^{-1}\end{array}$ & 1.63 & 1.93 & 1.44 & 1.44 & 1.38 & 1.38 & 1.39 & 1.40 & 1.47 & 1.50 & 1.20 & 1.21 & 1.11 & 1.12 \\
\hline $\begin{array}{l}\text { Metsulfuron methyl } \\
4 \mathrm{~g} \mathrm{ha}^{-1}\end{array}$ & 1.64 & 2.02 & 1.45 & 1.45 & 1.41 & 1.41 & 1.42 & 1.43 & 1.56 & 1.54 & 1.22 & 1.23 & 1.14 & 1.14 \\
\hline $\begin{array}{l}\text { Metsulfuron methyl } \\
8 \mathrm{~g} \mathrm{ha}^{-1}\end{array}$ & 1.62 & 1.72 & 1.42 & 1.43 & 1.39 & 1.37 & 1.40 & 1.40 & 1.52 & 1.49 & 1.17 & 1.17 & 1.12 & 1.04 \\
\hline Control & 1.57 & 1.56 & 1.40 & 1.41 & 1.26 & 1.36 & 1.36 & 1.37 & 1.45 & 1.42 & 1.15 & 1.13 & 1.07 & 1.06 \\
\hline$(P=0.05)$ & NS & 0.01 & 0.02 & 0.01 & 0.05 & 0.02 & 0.02 & 0.02 & 0.05 & 0.03 & 0.03 & 0.02 & 0.03 & 0.02 \\
\hline
\end{tabular}


Table.3 Effect of different treatments of metsulfuron methyl on chlorophyll ' $b$ ' $\left(\mathrm{mg} \mathrm{g}^{-1}\right)$ in wheat leaves at different time intervals

\begin{tabular}{|c|c|c|c|c|c|c|c|c|c|c|c|c|c|c|}
\hline \multirow[t]{3}{*}{ Treatments } & & & \multicolumn{12}{|c|}{ Days after herbicide application } \\
\hline & \multicolumn{2}{|c|}{ 0 } & \multicolumn{2}{|c|}{15} & \multicolumn{2}{|c|}{30} & \multicolumn{2}{|c|}{45} & \multicolumn{2}{|c|}{60} & \multicolumn{2}{|c|}{75} & \multicolumn{2}{|c|}{90} \\
\hline & $\begin{array}{l}\text { First } \\
\text { year }\end{array}$ & $\begin{array}{c}\text { Second } \\
\text { year }\end{array}$ & $\begin{array}{l}\text { First } \\
\text { year }\end{array}$ & $\begin{array}{c}\text { Second } \\
\text { year }\end{array}$ & $\begin{array}{l}\text { First } \\
\text { year }\end{array}$ & $\begin{array}{c}\text { Second } \\
\text { year }\end{array}$ & $\begin{array}{l}\text { First } \\
\text { year }\end{array}$ & $\begin{array}{c}\text { Second } \\
\text { year }\end{array}$ & $\begin{array}{l}\text { First } \\
\text { year }\end{array}$ & $\begin{array}{c}\text { Second } \\
\text { year }\end{array}$ & $\begin{array}{l}\text { First } \\
\text { year }\end{array}$ & $\begin{array}{c}\text { Second } \\
\text { year }\end{array}$ & $\begin{array}{l}\text { First } \\
\text { year }\end{array}$ & $\begin{array}{l}\text { Secon } \\
\text { d year }\end{array}$ \\
\hline $\begin{array}{l}\text { Metsulfuron } \\
\text { methyl } \\
2 \mathrm{~g} \mathrm{ha}^{-1}\end{array}$ & 0.32 & 0.33 & 0.15 & 0.14 & 0.08 & 0.07 & 0.14 & 0.10 & 0.25 & 0.13 & 0.12 & 0.22 & 0.09 & 0.16 \\
\hline $\begin{array}{l}\text { Metsulfuron } \\
\text { methyl } \\
4 \mathrm{~g} \mathrm{ha}^{-1}\end{array}$ & 0.34 & 0.38 & 0.16 & 0.17 & 0.10 & 0.09 & 0.15 & 0.13 & 0.29 & 0.16 & 0.16 & 0.25 & 0.12 & 0.21 \\
\hline $\begin{array}{l}\text { Metsulfuron } \\
\text { methyl } \\
8 \mathrm{~g} \mathrm{ha}^{-1}\end{array}$ & 0.30 & 0.32 & 0.13 & 0.11 & 0.06 & 0.04 & 0.13 & 0.08 & 0.24 & 0.11 & 0.11 & 0.21 & 0.09 & 0.15 \\
\hline Control & 0.30 & 0.35 & 0.12 & 0.08 & 0.09 & 0.02 & 0.10 & 0.05 & 0.22 & 0.13 & 0.10 & 0.21 & 0.08 & 0.16 \\
\hline$(\mathrm{P}=0.05)$ & 0.01 & 0.04 & 0.01 & 0.02 & 0.02 & 0.01 & 0.01 & 0.01 & 0.02 & 0.02 & 0.01 & 0.01 & 0.02 & 0.01 \\
\hline
\end{tabular}

Table.4 Effect of different treatments of metsulfuron methyl on total sugars $\left(\mathrm{mg} \mathrm{g}^{-1}\right)$ in wheat leaves at different time intervals

\begin{tabular}{|c|c|c|c|c|c|c|c|c|c|c|c|c|c|c|}
\hline \multirow[t]{3}{*}{ Treatments } & & & \multicolumn{12}{|c|}{ Days after herbicide application } \\
\hline & \multicolumn{2}{|c|}{ 0 } & \multicolumn{2}{|c|}{15} & \multicolumn{2}{|c|}{30} & \multicolumn{2}{|c|}{45} & \multicolumn{2}{|c|}{60} & \multicolumn{2}{|c|}{75} & \multicolumn{2}{|c|}{90} \\
\hline & $\begin{array}{l}\text { First } \\
\text { year }\end{array}$ & $\begin{array}{l}\text { Second } \\
\text { year }\end{array}$ & $\begin{array}{l}\text { First } \\
\text { year }\end{array}$ & $\begin{array}{l}\text { Second } \\
\text { year }\end{array}$ & $\begin{array}{l}\text { First } \\
\text { year }\end{array}$ & $\begin{array}{l}\text { Second } \\
\text { year }\end{array}$ & $\begin{array}{l}\text { First } \\
\text { year }\end{array}$ & $\begin{array}{l}\text { Second } \\
\text { year }\end{array}$ & $\begin{array}{l}\text { First } \\
\text { year }\end{array}$ & $\begin{array}{l}\text { Second } \\
\text { year }\end{array}$ & $\begin{array}{l}\text { First } \\
\text { year }\end{array}$ & $\begin{array}{l}\text { Second } \\
\text { year }\end{array}$ & $\begin{array}{l}\text { First } \\
\text { year }\end{array}$ & $\begin{array}{l}\text { Second } \\
\text { year }\end{array}$ \\
\hline $\begin{array}{l}\text { Metsulfuron methyl } \\
2 \mathrm{~g} \mathrm{ha}^{-1}\end{array}$ & 344.2 & 325.7 & 132.7 & 140.3 & 133.0 & 125.2 & 196.8 & 205.2 & 248.6 & 234.5 & 166.6 & 175.7 & 104.0 & 109.3 \\
\hline $\begin{array}{l}\text { Metsulfuron methyl } \\
4 \mathrm{~g} \mathrm{ha}^{-1}\end{array}$ & 345.1 & 325.3 & 133.6 & 146.2 & 133.8 & 128.8 & 234.9 & 213.0 & 253.2 & 245.0 & 184.4 & 179.3 & 106.9 & 109.2 \\
\hline $\begin{array}{l}\text { Metsulfuron methyl } \\
8 \mathrm{~g} \mathrm{ha}^{-1}\end{array}$ & 341.2 & 320.7 & 128.5 & 137.5 & 131.5 & 122.2 & 230.6 & 197.2 & 251.5 & 231.0 & 181.0 & 168.7 & 102.4 & 106.8 \\
\hline Control & 339.1 & 318.5 & 123.0 & 134.3 & 124.3 & 119.5 & 192.3 & 193.3 & 242.9 & 225.8 & 165.1 & 174.5 & 100.0 & 107.7 \\
\hline$(P=0.05)$ & NS & NS & 4.8 & 2.6 & 3.2 & 2.7 & 3.4 & 2.2 & 5.0 & 2.8 & 2.7 & 4.5 & NS & NS \\
\hline
\end{tabular}


This is indicative of effect of weed control by herbicide application. The increase in chlorophyll content in wheat leaves might be due to reduced crop weed competition and leading to availability of desired and required nutrients in the crop root zone resulting from solubilization of fixed forms of nutrients and their availability to crop during vegetative and reproductive stages. Similar results have been reported by Khokhar and Nepalia (2010). It was also observed that significantly higher value of chlorophyll content in wheat leaves was recorded at the recommended dose of metsulfuron methyl i.e. $4 \mathrm{~g} \mathrm{ha}^{-1}$ indicative of better weed control efficiency of the treatment. However, in general, maximum reduction in chlorophyll content in wheat leaves in metsulfuron methyl applied treatments was observed in metsulfuron methyl $8 \mathrm{~g} \mathrm{ha}^{-1}$ and this behavior can be explained on basis of increased reactive oxygen species production, which in turn resulted in damage to photosynthetic apparatus. The above findings are in accordance with results given by El-Rokiek et al., (2012).

\section{Total sugars}

Sugars have important functions throughout all the stages of plants. In plants, sugar production through photosynthesis is a vital process, and sugar status modulates and coordinates internal regulators and environmental cues that govern growth and development of plant. Data on effect of different treatments of metsulfuron methyl on total sugars in wheat leaves as shown in table 4 revealed that in all treatments, there was a decrease in sugars content in wheat leaves up to 15 during first year and 30 days during second year after herbicide application. Thereafter, during both years, sugar content in wheat leaves increased at 45 and 60 days and then ultimately decreased upto harvest of the crop.

Immediately after herbicide application corresponding to zero day, during both years the data on total sugars content in wheat leaves was not significant indicating that different treatments did not influence total sugars content significantly. At 15 days after herbicide application during first year of the study, a significant increase in total sugars in wheat leaves was observed in metsulfuron methyl treatments over control. The values varied from 133.6 to $123.0\left(\mathrm{mg} \mathrm{g}^{-1}\right)$ with maximum and minimum values exhibited in metsulfuron methyl $4 \mathrm{~g} \mathrm{ha}^{-1}$ and control respectively. A similar behavior of total sugars in wheat leaves was observed at next observation stage i.e. 30 days after herbicide application. Total sugars content in wheat leaves varied from 133.8 to $124.3\left(\mathrm{mg} \mathrm{g}^{-1}\right)$ with maximum and minimum in metsulfuron methyl $4 \mathrm{~g} \mathrm{ha}^{-1}$ and control, respectively. During the second year of experiment at both stages of observation i.e. 15 days and 30 days after herbicide application, metsulfuron methyl treatments recorded significantly higher values of sugars content in comparison to control. The values ranged from 146.2 to $134.3\left(\mathrm{mg} \mathrm{g}^{-1}\right)$ and 128.8 to 11.95 (mg $\left.\mathrm{g}^{-1}\right)$ at 15 and 30 days after herbicide application with maximum and minimum values exhibited by metsulfuron methyl $4 \mathrm{~g} \mathrm{ha}^{-1}$ and control respectively.

Among all the treatments at 45 days after herbicide application, during first year a significantly higher value of total sugars content i.e. $234.9 \mathrm{mg} \mathrm{g}^{-1}$ was observed in metsulfuron methyl $4 \mathrm{~g} \mathrm{ha}^{-1}$ followed by metsulfuron methyl $8 \mathrm{~g} \mathrm{ha}^{-1}\left(230.6 \mathrm{mg} \mathrm{g}^{-1}\right)$. The next best treatment was metsulfuron methyl $2 \mathrm{~g} \mathrm{ha}^{-1}$ which recorded 196.8 ( $\mathrm{mg} \mathrm{g}^{-1}$ dry weight) of total sugars content followed by control (192.3 $\left.\mathrm{mg} \mathrm{g}^{-1}\right)$. During second year, metsulfuron methyl $4 \mathrm{~g} \mathrm{ha}^{-1}(213.0$ $\mathrm{mg}$

$\mathrm{g}^{-1}$ dry weight) resulted in significantly higher value of total sugars followed by metsulfuron methyl $2 \mathrm{~g} \mathrm{ha}^{-1}\left(205.2 \mathrm{mg} \mathrm{g}^{-1}\right)$ and metsulfuron methyl $8 \mathrm{~g} \mathrm{ha}^{-1}\left(197.2 \mathrm{mg} \mathrm{g}^{-1}\right)$. Control recorded significantly lowest value $\left(193.3 \mathrm{mg} \mathrm{g}^{-1}\right.$ dry weight) of total sugar in wheat leaves.

At 60 day after herbicide application during first year of study, the values of total sugars varied from maximum value $253.2\left(\mathrm{mg} \mathrm{g}^{-1}\right)$ in metsulfuron methyl $4 \mathrm{~g} \mathrm{ha}^{-1}$ treatment to minimum value $242.9\left(\mathrm{mg} \mathrm{g}^{-1}\right)$ in control. All the three applied metsulfuron treatment were 
statistically at par with each other. During second year of study, significantly higher value of total sugars was observed in metsulfuron methyl $4 \mathrm{~g} \mathrm{ha}^{-1}\left(245.0 \mathrm{mg} \mathrm{g}^{-1}\right)$ followed by metsulfuron methyl $2 \mathrm{~g} \mathrm{ha}^{-1}\left(234.5 \mathrm{mg} \mathrm{g}^{-1}\right)$ and metsulfuron methyl $8 \mathrm{~g}$ $\mathrm{ha}^{-1}\left(231.0 \mathrm{mg} \mathrm{g}^{-1}\right)$. Significantly lower value for total sugars in wheat leaves was recorded in control $\left(225.8 \mathrm{mg} \mathrm{g}^{-1}\right)$.

With advancement of crop growth irrespective of treatments total sugars content in wheat leaves decreased both at 75 and 90 days after herbicide application. At 75 days after herbicide application during both years of study, significantly higher values for total sugars content were observed in all three applied treatments over control. The values for sugars content in wheat leaves ranged from 184.4 to $165.1 \mathrm{mg} \mathrm{g}^{-1}$ dry weight with maximum and minimum in metsulfuron methyl $4 \mathrm{~g} \mathrm{ha}^{-1}$ and control respectively in first year. During second year, the values ranged from 179.3 to $168.7 \mathrm{mg}$ $\mathrm{g}^{-1}$ dry weight with maximum and minimum in metsulfuron methyl $4 \mathrm{~g} \mathrm{ha}^{-1}$ and metsulfuron methyl $8 \mathrm{~g} \mathrm{ha}^{-1}$ respectively. As evident from Table 4 at 90 days after herbicide application, the data was found to be non-significant during both years of study.

The perusal of data revealed that total sugars in wheat leaves were greatly influenced by metsulfuron methyl treatments. Significant increase in all the metsulfuron methyl treatments was observed over control at all observation stages during both years of study. Similar results on sugars content in wheat plant was reported by Khokhar and Nepalia (2010). Plants under different weed control treatments might have more potential for nutrients absorption because of reduced crop weed competition and this might have led to high sugar content. Data on total sugars content also revealed that among all the three metsulfuron methyl treatments, highest value of sugars content was observed in metsulfuron methyl $4 \mathrm{~g}$ ha $^{-1}$ (recommended dose) suggesting weed control efficiency is maximum at recommended dose. Similar observations were also reported by El-Rokiek et al., (2012) and El-Metwally et al., (2012).The lower values of sugar content in metsulfuron methyl $8 \mathrm{~g} \mathrm{ha}^{-1}$ in comparison to other metsulfuron methyl applied treatment suggests that at higher dose herbicide after penetration into leaf cell wall bound to plastid where it might have accumulated and also resulted into interruption in sugars biosynthesis in leaves (Koley et al., 1993).

The results revealed that similar trend was observed in chlorophyll content and total sugars content chlorophyll content indicating the direct relationship of chlorophyll with sugar content. The efficient weed control by herbicide might have led to increase in the photosynthetic efficiency of plants and in turn led to higher sugar content in wheat plants.

The data on effect of different treatments on total sugars content of wheat grains revealed that during both years of study, all the metsulfuron methyl applied treatments increased the total sugars content in wheat grain as compared to control. The values of total sugars content in wheat varied from 69 to 58 per cent in first and 62 to 57 per cent in second year respectively with maximum and minimum value exhibited by metsulfuron methyl $4 \mathrm{~g} \mathrm{ha}^{-1}$ and control. An increase in total sugar content in wheat grain was observed in all the treatments of metsulfuron methyl as compared to control. Similar increase in total sugars in wheat grain was reported by El-Rokiek et al., (2012). Based on the results of our study, it could be concluded that the recommended dose of metsulfuron methyl i.e. $4 \mathrm{~g} \mathrm{ha}^{-1}$ have a nonsignificant effect on the biochemical attributes of wheat and can be used by farmers for better crop yield of wheat.

\section{References}

Anonymous. 2012-13. Economic survey of Himachal Pradesh. p 48-49

Blair, A.M. and Martin, T.D. 1988. A review of the activity, fate and mode of action of sulfonylurea herbicides. Pesticide Science. 22, 195-219 
Brown, H.M. 1990. Mode of action, crop selectivity, and soil relations of the sulfonylurea herbicides. Pesticide Science. 29, 263-281

Chitband, A. A., Ghorbani, R., Mohassel, M.H.R., Fizabadi, A.Z. and Abbaspoor, M. 2013. Jointed Effects of Mesosulfuron-Methyl + IodosulfuronMethyl-Sodium and ClodinafopPropargyl Mixed with Adjuvants on wild Oat (Avena ludoviciana Durieu.). International Journal of Agronomy and Plant Production. 4, 2166-2173

El-Metwally, I.M., Dawood, M.G., Messiha, N.K., El-Masry, R.R. and Shaheen, A.M.M. 2012. Changes in minerals, carbohydrate, flavonoid, phenolic contents and yield of onion bulbs as affected by some herbicidal weed management. Journal of Applied Sciences Research. 8, 930-936

El-Rokiek, Kowthar, G., Mohamed, E., ElAwadi and Abd El-Wahed, M.S.A. 2012. Physiological responses of wheat plants and accompanied weeds to derby herbicide and $\beta$ - sitosterol bioregulator. Journal of Applied Sciences Research. 8, 1918-1926

Gomez, K.A. and Gomez, A.A. 1989. Statistical procedure for Agricultural Research. A Wiley Inter Science Publication, John Wiley and Sons, New York, p. 25-28

Hedge, J.E. and Hofreiter, B.T. 1962. In: Carbohydrate Chemistry, 17(Whistler RL and JN Be Miller, Eds.), Academic Press, New York.

Hiscox, J.D. and Israelstam, G.F. 1979. A method of extraction of chlorophyll from leaf tissue without maceration. Canadian Journal of Botany. 57, 1332-1334

Khokhar, A.K. and Nepalia, V. 2010. Effect of herbicides and nutrient management on weed flora, nutrient uptake and yield of wheat (Triticum aestivum) under irrigated conditions. Indian Journal Weed Science. 42, $14-18$

Kumar, S., Angiras, N.N., Rana, S.S. and Sharma, N. 2009. Alternative method of isoproturon application in wheat. Himachal Journal of Agricultural Research.35, 31-33

Li, Z.J., Xu, J.M., Muhammad, A. and Ma, G.R. 2005. Effect of bound residues of metsulfuron-methyl in soil on rice growth. Chemosphere.58, 1177-1183

Singh, G. and Singh, M. 2002. Bioefficacy of metsulfuron methyl in combination with isoproturon for control of grassy and nongrassy weed in wheat. Indian Journal of Weed Science. 34, 9-12

Zanardini, E., Arnoldi, A., Boschin, G., Agostina, A.D., Negri, M. and Sorlini, C. 2002. Degradation pathways of Chlorsulfuron and metsulfuron- methyl by Pseudomonas fluorescens strains. Annals of Microbiology. 52, 25-37

\section{How to cite this article:}

Nitasha Thakur, Neelam Sharma and Yeshwant Singh. 2018. Studies on Effect of Metsulfuron Methyl on Chlorophyll, Sugar Content in Wheat Leaves and Its Relationship with Grain Sugar Content. Int.J.Curr.Microbiol.App.Sci. 7(05): 2052-2060. doi: https://doi.org/10.20546/ijcmas.2018.705.241 